\title{
Intraspecific variation and geographic study of Lonicera insularis (Caprifoliaceae) based on chloroplast DNA sequences
}

\author{
Keum Seon Jeong, Mi Sun Kim, Woong Lee and Jae-Hong Pak* \\ Department of Biology Kyungpook National University 1370 Sankyuk-dong, Buk-gu, Daegu 720-701, Korea \\ (Received 12 July 2014; Revised 10 September 2014; Accepted 16 September 2014)
}

\section{엽록체 DNA를 이용한 섬괴불나무(Lonicera insularis Nakai)의 종내변이 및 지리학적 연구}

\author{
정금선 · 김미선 · 이 웅 · 박재홍*
}

경북대학교 자연과학대학 생물학과

\begin{abstract}
Lonicera insularis Nakai (Caprifoliaceae) is Korean endemic plant that lives along the shore of Ulleungdo and Dokdo. The aim of this study is to construct a phylogenetic relationship within six species (L.maackii, L.chrysantha, L.subsessilis, L. harai, L. morrowii) of genus Lonicera L. and Wigela subsessilis as outgroup and intraspecific variation of $L$. insularis using chloroplast DNA five regions sequences. Sequence analysis revealed that both $L$. insularis and $L$. morrowii showed complete homologies in the intergenic regions of $\operatorname{trn} \mathrm{L}-t r n \mathrm{~F}$, $t r n \mathrm{~S}-\operatorname{trn} \mathrm{G}, p s b \mathrm{M}-\operatorname{trn} \mathrm{D}$ and $m a t \mathrm{~K}$ coding region. However, sequence in the $p e t \mathrm{~N}-p s b \mathrm{M}$ intergenic region showed a single nucleotide difference between both species, thus we designated them as CP01 and CP02. The plants having CP01 are prevalent in the Ulleungdo and Dokdo, while L. insularis and L. morrowii from Ulleungdo and of Dokdo, and Japan have CP02. This confirmed the existence of two cp DNA lineages with different geographical distributions. We can infer the allopatric speciation by geographical barrier. The result will provide the important basal data to study speciation and specie evolution of ocean islands such as Ulleungdo and Dokdo.
\end{abstract}

Keywords: Lonicera insularis, Ulleungdo, Dokdo, Chloroplast DNA, intraspecific variation

적 요: 섬괴불나무(Lonicera insularis Nakai)는 인동과(Caprifoliaceae) 인동속(Lonicera L.) 에 속하는 관목으로 울릉 도와 독도의 해안가 지역에 분포하는 한국특산식물이다. 섬괴불나무와 인동속의 근연종인 괴불나무, 청괴불나무, 각시괴불나무, 길마가지나무, L. morrowii, 병꽃나무 7분류군과의 유연관계를 밝히고, 섬괴불나무의 종내 변이를 확인하기 위해 엽록체 DNA 5개 영역의 염기서열을 분석하였다. 분석결과 전체 $3.2 \mathrm{~kb}$ 의 염기서열이 결정되었고, 섬괴불나무와 L. morrowii 에서 2개의 엽록체 DNA haplotype(CP01-02)이 결정되었다. 섬괴불나무는 한 개의 염기 치환으로 CP01 type과 CP02 type으로 구별되었으며, 일본의 L. morrowii와는 CP02 type을 공유하였다. 섬괴불나무 에서 확인 된 두 개의 CP type은 1) 진화적으로 뚜렷한 두 개 이상의 계통을 가지며, 이는 하나 이상의 유입경로 를 통해 울릉도로 유입되었을 가능성을 높게 지지한다. 그리고, 2) 형태학적으로 구별되는 섬괴불나무와 $L$. morrowii의 CP type의 공유는 두 종의 지리적인 장벽에 의한 이소적종분화의 결과로 추론할 수 있다. 본 연구에서 확인된 울릉도와 독도의 섬괴불나무의 종내 변이 및 다양성에 관한 결과는 울릉도 및 독도 식물의 분자생물지리 학적 연구로 대양섬의 생물학적 진화양상과 종 분화 과정에 중요한 기초 자료로 활용될 것이다.

주요어: 섬괴불나무, 울릉도, 독도, 엽록체 DNA, 종내변이

\footnotetext{
*Author for correspondence: jhpak@knu.ac.kr
}

http://www.pltaxa.or.kr

Copyright (C) 2014 the Korean Society of Plant Taxonomists 
섬괴불나무(Lonicera insularis Nakai)는 인동과(Caprifoliaceae) 인동속(Lonicera L.) 에 속하는 관목으로 울릉 도와 독도의 해안가 지역에 분포하는 한국특산식물이다. 인동속은 약 200 여종이 전세계에 분포하고 있으며, 중국 (약 100 여종), 일본(약 25 여종), 한국(약 30 여종)을 중심으 로 동아시아 지역이 주요 분포지로 알려져 있다(Nakai, 1927; Cronquist, 1981; Ohwi, 1984; Chung, 1985).

울릉도와 독도는 해저 화산활동으로 기원된 대륙과 한 번도 연결된 적이 없는 대양섬으로(Kim, 1985), 지리적으 로 한반도와 러시아 대륙, 일본 열도에 둘러 싸여 있다. 이 러한 지리적인 위치는 울릉도와 독도 식물들의 다양한 방 법을 통한 원거리 분산의 가능성을 높여 식물의 유입과 진화과정에도 큰 영향을 미쳤을 것이다(Lee and Pak, 2010). 울릉도는 다른 비슷한 면적의 섬 지역에 비해 특산 종의 비율이 높으며, 지금까지 약 30 여종의 특산식물이 보고 되어있다. Sun and Stuessy(1998)는 이들 중 대부분은 대륙 선구종들이 원거리 분산에 의해 울릉도와 독도에 정 착한 후 향상진화(anagenesis)를 통해 종의 진화가 이루어 졌을 것이며, 지금의 형태학적 유전학적 다양성을 획득하 게 되었을 것으로 생각하였다.

식물종들의 현재 분포양상은 이주와 멸종의 결과로 돌 연변이, 유전적 부동 및 유전자 확산 등 여러 가지 요인에 의해 그 유전적 변이의 분포양상이 다양하게 나타난다 (Hewitt, 2000). 유전적 변이에 의해 확인되는 다양한 유전적 분포양상은 식물의 기원과 진화를 밝히기 위한 중요한 정 보이다. 이러한 식물의 기원과 진화에 관한 연구 방법으로 는 주로 분자학적 연구가 많이 이루어지고 있으며, 그 중 엽 록체 DNA는 느린 진화율과 재조합하지 않는 특성 때문에 집단형성 경로를 찾기 위한 유용한 marker로 이용된다 (Rendell and Ennos, 2003; Heuertz et al., 2004). 엽록체 DNA를 이용한 분자학적 연구는 계통유연관계 분석 뿐만 아니라 유전자 이동, 유전자 확산 그리고 지리적 분포를 조사하는 데 유용한 정보를 제공하고 있다(Schaal et al., 1998; Taberlet et al., 1998). 울릉도에 분포하는 식물종에 대한 분자생물지 리학적 연구로는 섬단풍나무와 우산고로쇠의 엽록체 DNA 염기서열을 이용한 연구가 있으며, 울릉도의 섬단풍 나무와 우산고로쇠는 각각 한반도의 당단풍나무와 고로쇠 나무에서 유래되었을 가능성을 제시하였다(Sun and Stuessy, 1998; Jakubowsky et al 2006). 또한 최근의 Lee and $\operatorname{Pak}(2010)$ 의 연구에서는 울릉도와 독도의 자생하는 섬기린 초의 엽록체 DNA 염기서열 분석을 통해 섬기린초의 종내 변이와 뚜렷한 haplotype의 분포양상을 확인하고, 진화적으 로 서로 다른 두 개 이상의 계통이 있음을 추정하였다.

울릉도와 독도에 분포하는 섬괴불나무는 소지가 비어 있고, 꽃은 5-6월에 개화하고 꽃색은 백색에서 황색으로 변한다. 식물체 전체에 밀생하는 부드러운 융모는 다른 분류군들과 구별 짓는 주요 고유 형질이다(Nakai, 1927). 섬괴불나무의 계통학적 연구와 기원에 관한 연구는 Sun
(2002), Jeon(1993)등의 연구가 있다. Jeon (1993)의 연구는 섬괴불나무를 포함한 sect. Ochranthae 분류군들의 외부형 태학적 형질을 이용한 계통학적 연구로 섬괴불나무는 소 포가 완전히 분리되거나 기부만이 유합되는 공통적인 특 징으로 각시괴불나무, 물앵도나무, 괴불나무와 가까운 유 연관계를 확인하였다. 그러나, RAPD를 이용한 분자학적 연구에서는 섬괴불나무는 길마가지나무와 더 가까운 유 연관계를 확인하여 형태학적 연구와는 다른 결과를 나타 내었다(Jeon, 1993). Sun(2002)은 일본의 북해도와 혼슈의 동해 지역에 자생하고 있는 L. morrowii A. Gray를 울릉도 에 자생하는 섬괴불나무의 기원종으로 추론하여, 일본의 Oki 섬으로부터 독도와 울릉도로 유입되었을 가능성을 제시했다. 이는 독도의 지사학적 연령이 울릉도보다 더 오래되었고, 과거에는 독도가 현재보다 더 큰 화산으로 형성되어 훨씬 더 다양한 환경을 이루었을 가능성 때문일 것으로 설명하고 있다. 두 종은 외부형태학적으로 섬괴불 나무는 L. morrowii에 비해 잎이 넓으며 화관이 5열하지 않 는 형태학적 차이를 보이고 있어(Lee, 1996) 형태적으로 구별되지만, 두 종의 명확한 유연관계 파악을 위해서는 형태학적, 유전학적 등의 연구가 필요하다.

또한, 현재 독도에 분포하고 있는 섬괴불나무는 $\operatorname{Kim}(1998)$ 의 분포기록에 의하면, 1974년부터 1996년까지 울릉도로부터 총 425 그루가 식재 된 것으로 확인되며 이 후 현재까지 그 중 몇 개체만이 잔존하는 것으로 추정하고 있어 독도 섬괴불나무의 기원에 관한 연구가 필요하다.

본 연구에서는 울릉도와 독도에 분포하는 특산식물인 섬괴불나무의 엽록체 DNA 염기서열을 이용한 분자학적 연구를 통해 근연종간의 유연관계를 밝히고, 기원을 추정 하여 울릉도와 독도의 식물지리학적 중요성과 보전의 필 요성을 설명하는데 필요한 기초 자료로 활용하고자 한다.

\section{재료 및 방법}

\section{재료}

울릉도, 독도, 한반도로부터 섬괴불나무, 각시괴불나무, 길마가지나무, 괴불나무, 청괴불나무, 병꽃나무와 일본 Oki 섬에서 채집한 L. morrowii A. Gray 등 7개 분류군의 증거표 본을 만들었다. 원기재문과 참고문헌(Nakai, 1927, 1938; Lee, 1979; Ohwi, 1984)을 이용하여 동정하고 경북대학교 표본실 $(\mathrm{KNU})$ 에 보관하였다. 엽록체 DNA의 염기 서열 분석에 이 용한 분류군에 대한 채집지를 Table 1에 정리하였다.

\section{DNA 추출, $\mathrm{PCR}$ 과 염기서열 및 계통수 작성}

DNA 추출은 생체 또는 건조표본을 이용하였다(Table 1). DNA 추출은 Dolye and Dolye (1987)의 CTAB (Cetyltrimethyl-ammonium Bromide) 방법과 DNeasy Plant Mini Kits (Qiagen, Valencia, California)를 이용하였다. DNA 증폭은 $10 \mathrm{ng}$ 의 주형 DNA, $10 \mathrm{pmol}$ 의 양방향 primer, 1 unit의 Taq 
Table 1. Sampling site of Lonicera L. used for morphological and molecular analysis.

\begin{tabular}{|c|c|c|c|}
\hline Species & Locality & Sample No. & Coordinates (N/E) \\
\hline \multirow{7}{*}{$\begin{array}{l}\text { L. insularis Nakai } \\
\text { (섬괴불나무) }\end{array}$} & Gyeongsangbuk-do, Is. Ulleung, Dodong & La1 15 & $37^{\circ} 29^{\prime} 04.7^{\prime \prime} \mathrm{N}, 130^{\circ} 54^{\prime} 45.8^{\prime \prime} \mathrm{E}$ \\
\hline & Gyeongsangbuk-do, Is. Ulleung, Summok & La16 18 & $37^{\circ} 32^{\prime} 29.2^{\prime \prime} \mathrm{N}, 130^{\circ} 54^{\prime} 54.5^{\prime \prime} \mathrm{E}$ \\
\hline & Gyeongsangbuk-do, Is. Ulleung, Cheonbu & La19 35 & $37^{\circ} 32^{\prime} 33.0^{\prime \prime} \mathrm{N}, 130^{\circ} 53^{\prime} 09.4^{\prime \prime} \mathrm{E}$ \\
\hline & Gyeongsangbuk-do, Is. Ulleung, Namyang & La36 39 & $37^{\circ} 27^{\prime} 28.4^{\prime \prime} \mathrm{N}, 130^{\circ} 52^{\prime} 14.4^{\prime \prime} \mathrm{E}$ \\
\hline & Gyeongsangbuk-do, Is. Ulleung, Hyeonpo & La40 & $37^{\circ} 31^{\prime} 30.7^{\prime \prime} \mathrm{N}, 130^{\circ} 49^{\prime} 12.8^{\prime \prime} \mathrm{E}$ \\
\hline & Gyeongsangbuk-do, Is. Dokdo, Dong-do & La41 43 & $37^{\circ} 14^{\prime} 30.4^{\prime \prime} \mathrm{N}, 131^{\circ} 51^{\prime} 51.9^{\prime \prime} \mathrm{E}$ \\
\hline & Gyeongsangbuk-do, Is. Dokdo, Seo-do & La44 45 & $37^{\circ} 14^{\prime} 37.9^{\prime \prime} \mathrm{N}, 131^{\circ} 51^{\prime} 33.3^{\prime \prime} \mathrm{E}$ \\
\hline \multirow{2}{*}{$\begin{array}{l}\text { L. maackii (Rupr.) Maxim } \\
\text { (괴불나무). }\end{array}$} & Gyeonggi-do pocheonsi soheul-eub & Lm1 & $37^{\circ} 55^{\prime} 22.5^{\prime \prime} \mathrm{N}, 127^{\circ} 23^{\prime} 09.8^{\prime \prime} \mathrm{E}$ \\
\hline & Gyeongsangbuk-do, Mt. Unmun-san & $\mathrm{Lm} 2$ & $35^{\circ} 40^{\prime} 02.7^{\prime \prime} \mathrm{N}, 128^{\circ} 57^{\prime} 57.5^{\prime \prime} \mathrm{E}$ \\
\hline $\begin{array}{l}\text { L. chrysantha Turcz } \\
\text { (각시괴불나무) }\end{array}$ & Jeonllabuk-do Mt. Deogyu-san & Lc1 & $35^{\circ} 51^{\prime} 44.9^{\prime \prime} \mathrm{N}, 127^{\circ} 44^{\prime} 33.0^{\prime \prime} \mathrm{E}$ \\
\hline \multirow[t]{2}{*}{$\begin{array}{l}\text { L. subsessilis Rehder } \\
\text { (청괴불나무) }\end{array}$} & Gyeongsangbuk-do youngyang-gun & Ls1 & $36^{\circ} 40^{\prime} 40.5^{\prime \prime} \mathrm{N}, 129^{\circ} 05^{\prime} 46.0^{\prime \prime} \mathrm{E}$ \\
\hline & Gangwon-do Mt. Seorak-san & Ls2 & $37^{\circ} 32^{\prime} 19.3^{\prime \prime} \mathrm{N}, 128^{\circ} 14^{\prime} 55.1^{\prime \prime} \mathrm{E} \mathrm{E}$ \\
\hline $\begin{array}{l}\text { L. harai Makino } \\
\text { (길마가지나무) }\end{array}$ & Jeju-do, Aewol-eup & Lh1 & $33^{\circ} 27^{\prime} 55^{\prime \prime} \mathrm{N}, 126^{\circ} 46^{\prime} 40^{\prime \prime} \mathrm{E}$ \\
\hline L. morrowii Gray & Shimane Is. Oki, Japan & Lw1,2 & $36^{\circ} 17^{\prime} 45^{\prime \prime} \mathrm{N}, 133^{\circ} 21^{\prime} 45^{\prime \prime} \mathrm{E}$ \\
\hline $\begin{array}{l}\text { W. subsessilis L.H.Bailey } \\
\text { (병꽃나무) }\end{array}$ & Gyeongsagnam-do Mt. Gaji-san & Ws1 & $35^{\circ} 40^{\prime} 21.7^{\prime \prime} \mathrm{N}, 128^{\circ} 58^{\prime} 18.6^{\prime \prime} \mathrm{E}$ \\
\hline
\end{tabular}

Table 2. Primers used for amplification of intergenic and coding regions of chloroplast genes in this study.

\begin{tabular}{|c|c|c|c|}
\hline Falnaking Genes & Primer sequence & $\operatorname{Tm}\left({ }^{\circ} \mathrm{C}\right)$ & References \\
\hline $\operatorname{trn} \mathrm{L}-\operatorname{trn} \mathrm{F}$ & $\begin{array}{l}\text { F 5' AGG GTT CAA GTC CCT CTA TCC C 3' } \\
\text { R 5' GAT TTG AAC TGG TGA CAC GAG G 3' }\end{array}$ & 50 & Taberlet et al.(1991) \\
\hline $\operatorname{trnS}-\operatorname{trn} \mathrm{G}$ & $\begin{array}{l}\text { F 5' AGA TAG GGA TTC GAA TTC GAA CCC TCG GT3' } \\
\text { R 5' TTT TAC CAC TAA ACT ATA CCC GC 3' }\end{array}$ & 59 & Hamilton(1999) \\
\hline$p e t \mathrm{~N}-p s b \mathrm{M}$ & $\begin{array}{l}\text { F 5' GTC TTG CTT GGG CTG CTT TAA TGG 3' } \\
\text { R 5' TTC TTG CAT TTA TTG CTA CTG C 3' }\end{array}$ & 55 & Lee and Wen(2004) \\
\hline$p s b \mathrm{M}-t r n \mathrm{D}$ & $\begin{array}{l}\text { F 5' GCA GTA GCA ATA AAT GCA AGA A 3' } \\
\text { R 5' GGG ATT GTA GTT CAA TTG GT 3' }\end{array}$ & 55 & Lee and Wen(2004) \\
\hline matK & $\begin{array}{l}\text { F } 5^{\prime} \text { TGT CAT AAC CTG CAT TTT CC 3' } \\
\text { R 5' TGG GTT GCT AAC TCA ATG G 3' }\end{array}$ & 55 & Johnson and Soltis(1994) \\
\hline
\end{tabular}

F: forward, R: reverse, Tm: annealing temperature

DNA polymerase(Takara사의 Ex Taq)를 포함한 $20 \mathrm{ul}$ 증폭용 반응액을 제작하여, Perkin Elmer사의 PE 2400기계를 이용 하였다. 증폭을 위한 primer는 trnE-trnF intergenic region, trnS-trn $\mathrm{G}$ intergenic region, $p e t \mathrm{~N}-p s b \mathrm{M}$ intergenic region, $p s b \mathrm{M}$ $\operatorname{trn} \mathrm{D}$ intergenic region, matK gene을 이용하였다(Table 2). 증 폭반응은 $95^{\circ} \mathrm{C}$ 에서 3 분간 incubation후, $94^{\circ} \mathrm{C} 1$ 분간 denaturation, $50^{\circ} \mathrm{C}-59^{\circ} \mathrm{C} 1$ 분간 annealing, $72^{\circ} \mathrm{C}$ 에서 1 분간 extension을 35-38회 반복하였으며, $72^{\circ} \mathrm{C}$ 에서 10 분간 final extension을 수행하였다(Hamilton, 1999; Johnson and Soltis, 1994; Lee and Wen, 2004). 증폭반응 후, 증폭 여부 및 증폭산
물의 농도는 $\lambda \mathrm{DNA}$ 를 marker로 이용하여 $1 \%$ agarose gel 상 에서 전기영동 후 확인하였다. 각 분류군의 엽록체 DNA region의 염기서열은 CLUSTAL X (Thompson et al., 1997) program을 이용하여 정리한 후, BIOEdit program을 사용하 여 보정하였다. 계통분석(phylogenetic analysis)은 인동속의 6분류군과 외군인 병꽃나무로부터 얻어진 엽록체 DNA region의 염기서열을 근거로 PAUP $4.0 \mathrm{~b} 10$ program (Swofford, 2002)을 이용하여 수행하였다. 전체 염기서열 중 gap은 모두 결여형질(missing character)로 처리하였으며 정 렬된 염기서열의 모든 character는 'unordered', 'unweighted', 
Table 3. Gene bank numbers of submitted sequences for Lonicera L. used in this study.

\begin{tabular}{|c|c|c|c|c|c|}
\hline Species & $\operatorname{trn} \mathrm{L}-t r n \mathrm{~F}$ & $\operatorname{trnS}-t r n \mathrm{G}$ & $p e t \mathrm{~N}-p s b \mathrm{M}$ & $p s b \mathrm{M}-t r n \mathrm{D}$ & matK* \\
\hline L. harae & AB969749 & AB969758 & AB969766 & AB969773 & $\mathrm{a}$ \\
\hline L. chrysantha & AB969750 & AB969757 & AB969765 & AB969772 & $\mathrm{a}$ \\
\hline L. maackii & AB969751 & AB969759 & AB969767 & AB969774 & $\mathrm{a}$ \\
\hline L. morrowii & AB969752 & AB969760 & AB969768) & AB969775 & $\mathrm{a}$ \\
\hline L. subsessilis & AB969753 & AB969761 & AB969769 & AB969776 & $\mathrm{a}$ \\
\hline L. insularis & AB969755 & AB969756 & $\begin{array}{l}\text { AB969763(CP01) } \\
\text { AB969764(CP02) }\end{array}$ & AB969771 & $\mathrm{a}$ \\
\hline W. subsessilis & AB969754 & AB969762 & AB969770 & AB969777 & $\mathrm{a}$ \\
\hline
\end{tabular}

*a: Not yet given the accession number of those sequences from NCBI

character로 설정하였다. 계통분석은 heuristic search를 이용 하여 수행하였으며 계통수는 병꽃나무를 외군으로 선정 하여 rooting하였다. Bootstrap value를 얻기 위해 parsimony analysis에 사용한 선택 사항을 모두 적용하여 heuristic search를 1000 번 반복하였다. 본 연구에서 얻은 모든 염기 서열 자료는 GeneBank에 제출하였다(Table 3).

\section{결과 및 고찰}

\section{엽록체 DNA의 non-coding region 염기서열 분석}

섬괴불나무, 괴불나무, 청괴불나무, 각시괴불나무, 길 마가지나무, L. morrowii, 병꽃나무 7 분류군에 대한 $\mathrm{cp}$ DNA 5 개 영역의 염기서열은 $t r n \mathrm{~L}-t r n F$ region에서 $385 \mathrm{bp}$, $\operatorname{trnS}-t r n \mathrm{G}$ region에서 700bp, pet $\mathrm{N}-p s b \mathrm{M}$ region $545 \mathrm{bp}, p s b \mathrm{M}-$ $t r n \mathrm{D}$ region $780 \mathrm{bp}, m a t \mathrm{~K}$ gene region $840 \mathrm{bp}$ 로 총 $3.2 \mathrm{~kb}$ 의 염 기서열을 결정하였다. 섬괴불나무는 4 개 $\mathrm{cp}$ DNA region(trnL-trnF region, $t r n \mathrm{~S}-t r n \mathrm{G}$ region, $p s b \mathrm{M}-t r n \mathrm{D}$ region, $m a t \mathrm{~K}$ gene region)의 약 $2.6 \mathrm{~kb}$ 의 염기서열에서는 일본 $L$. morrowii와 완전히 일치하였다. 그러나, $\operatorname{pet} \mathrm{N}-p s b \mathrm{M}$ intergenic region에서는 한 염기 치환으로 두 TYPE(CP01, $\mathrm{CP} 02)$ 으로 구별되었다.

울릉도 섬괴불나무 40 개체, 독도 섬괴불나무 4 개체와 L. morrowii의 $p e t \mathrm{~N}-p s b \mathrm{M}$ 염기서열에서는 한 개의 염기치 환으로 $\mathrm{CP} 01, \mathrm{CP} 02$ 의 haplotype로 구별되었다(Fig. 1). 울릉 도에서 채집한 섬괴불나무에서는 haplotype $\mathrm{CP} 01$ 과 $\mathrm{CP} 02$ 가 확인되었고, 독도의 동도 개체에서는 haplotype $\mathrm{CP} 02$, 서도의 개체에서는 haplotype $\mathrm{CP} 01$ 이 확인되었다. 일본 Oki섬에서 채집한 L. morrowii 개체에서는 $\mathrm{CP} 02$ 가 관찰되 었다. 집단간 유연관계를 결정하고 확인하기 위해 neighbor-joining(NJ) tree를 Fig. 2에 나타내었다. 울릉도와 독도의 섬괴불나무와 일본의 L. morrowii는 $100 \%$ bootstrap value로 그릅 지어졌다.

\section{엽록체 DNA의 petN-psbM region에서 haplotype 분석}

엽록체 DNA의 $p e t \mathrm{~N}-p s b \mathrm{M}$ region에서 확인된 7 haplotype

\section{CP01 L.insularis \\ CPO2 L.insularis \\ $541 \quad 550$ \\ АТTTТСTAА \\ CP02 L.morrowii \\ АТTTTATTAA \\ АТТTТАТАA}

Fig. 1. The pet $\mathrm{N}-p s b \mathrm{M}$ cpDNA sequences of 2 haplotype (CP0102) of Lonicera insularis and L. morrowii.

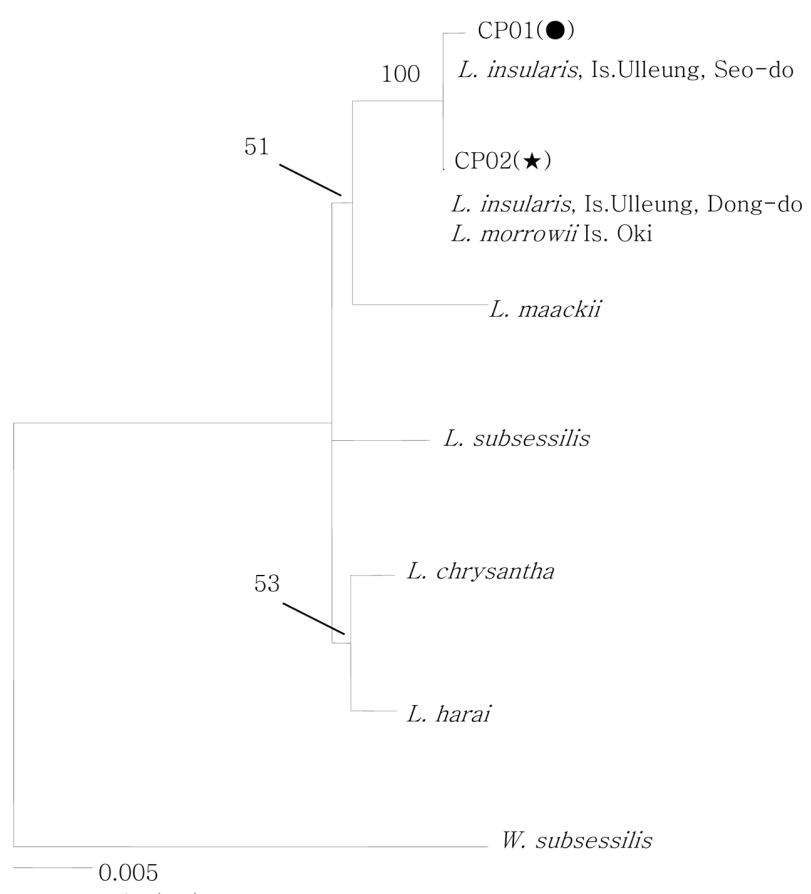

Fig. 2. NJ trees based on the all sequences of the spacer, gaps, among the cpDNA of Lonicera insularis, L. morrowii, L. maackii, L. subsessilis, L. chrysantha, L. harai and Weigela subsessilis. Numbers along internodes show the bootstrap probability in percentage based on 1,000 replicate analyses.

은 울릉도, 독도, 한반도, 일본에서 나타났다. 울릉도와 독 도의 섬괴불나무에서 확인된 $\mathrm{CP} 01$ 은 울릉도의 도동, 현 포, 남양, 섬목, 천부 등 해안가 일대와 독도의 동도에 분포 하는 것으로 확인되었다. 울릉도의 도동, 현포, 남양, 섬목 


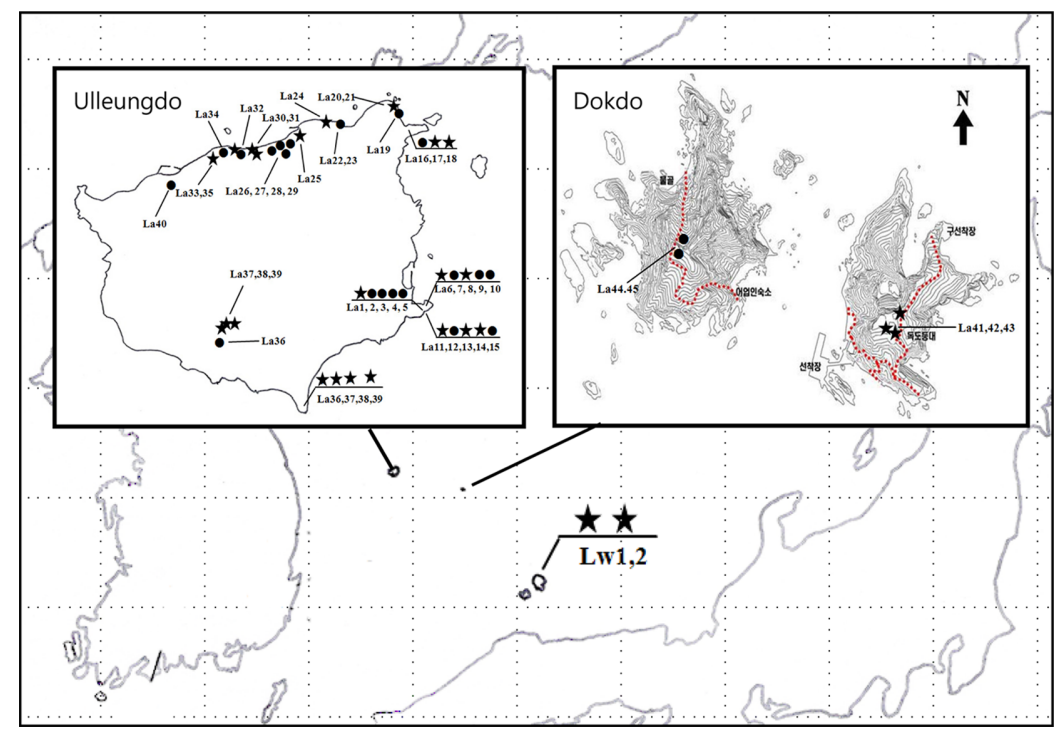

Fig. 3. Localities and distribution of pet $\mathrm{N}-p s b \mathrm{M}$ cpDNA haplotype of 47 sample of of Lonicera insularis (La) and L. morrowii (Lw); cpDNA haplotype $=\mathrm{CP} 01: \bullet, \mathrm{CP} 02: \star$.

지역과 독도의 서도의 섬괴불나무와 일본 $\mathrm{Oki}$ 섬의 $L$. morrowii에서 $\mathrm{CP} 02$ 가 확인되었다(Fig. 3).

\section{고 찰}

\section{울릉도와 독도 섬괴불나무의 종내 변이와 기원}

인동속의 분류군들은 꽃의 색이 흰색에서 점차 황색으 로 변하며 열매는 장과로 2 개씩 달리는 형질을 공유한다. 섬괴불나무와 L. morrowii는 형태학적으로 매우 유사하다. 이들 두 분류군은 화경의 길이가 $10 \mathrm{~mm}$ 이상으로 다른 절 내 다른 분류군들에 비해 길고, 열매가 7-8월에 붉게 성숙 한다. 또한 울릉도와 독도(동도 및 서도)의 섬괴불나무 개 체에서는 형태학적 차이를 보이지 않았으며, 다른 종에 비해 잎 전체에 융모가 밀생한다. 엽록체 DNA를 이용한 인동속 식물의 유연관계분석에서 울릉도와 독도의 섬괴 불나무는 일본의 L. morrowii는 $100 \%$ bootstrap value로 가 까운 유연관계를 확인하였다(Fig. 2).

울릉도와 독도의 섬괴불나무의 엽록체 DNA 분석결과 에서 두 가지 패턴(CP01, CP02)이 확인되었다. 엽록체 DNA CP01 type은 울릉도와 독도의 개체로부터만 확인되 었으며, 엽록체 DNA CP02 type은 울릉도와 독도의 개체 뿐 만 아니라 일본의 L. morrowii에서도 확인되었다. 울릉 도와 독도의 섬괴불나무에서 엽록체 DNA CP type의 뚜렷 한 지리적인 분포양상은 확인되지 않았으나, 두 개의 엽 록체 DNA CP type은 섬괴불나무가 진화적으로 뚜렷한 두 개 이상의 계통을 가지며, 하나 이상의 유입경로를 가지 고 유입되었을 가능성을 높게 지지하고 있다. 또한, 섬괴 불나무에서 확인된 엽록체 DNA type은 본 연구에서 이용 한 한반도의 인동속 식물에서는 확인되지 않았으며, 일본 의 L. morrowii와 엽록체 DNA CP02 type을 공유하고 있다.
이전 연구에서 $\operatorname{Sun}(2002)$ 은 형태학적 유사성과 지리학적 연구로 섬괴불나무의 기원종이 L. morrowii일 가능성을 제 시한 바 있다. 본 연구 결과에서 확인된 두 종의 엽록체 DNA CP type(CP02)의 공유는 Sun(2002) 가설을 지지하고 있지만, 울릉도와 독도의 섬괴불나무 유입경로에 대한 연 구는 좀더 명확한 근거 자료가 필요할 것으로 생각된다.

독도에 분포하고 있는 목본 식물에 대해서는 과거 여러 식재 사업 등이 이루어진 바 있다(Kim, 1998). 분포 기록에 관한 조사 문헌에서는 섬괴불나무의 분포 기록에 대해 1974년 이후 식재를 시작으로 1996년까지 총 425그루의 섬괴불나무를 울릉도로부터 이식하여 식재 된 것으로 기 록하고 있다. 그러나 현재 독도의 동도와 서도의 섬괴불 나무는 각각 10 개체와 5-6개체로 극히 일부 개체만이 분 포하고 있어 이전 문헌의 보고와는 다소 차이가 있다. 또 한 본 연구에서는 독도에 분포하는 섬괴불나무는 서도와 동도에서 각각 다른 DNA CP type이 확인되어 식재에 관 한 확인 연구는 좀 더 이루어져야 할 것으로 생각된다. 독 도는 대양섬으로 내륙과 연결된 적이 없고, 얕은 토양층 과 여러 환경적인 요인이 목본 식물이 생육하기에는 열악 한 환경을 가지고 있다. 뿐 만 아니라, 울릉도와 독도의 종 의 유입과 산포 등에 관한 이전 연구 결과는 거의 전무하 다. 다양한 종의 종자 산포 중 섬괴불나무의 열매와 같이 과육을 가지는 열매의 경우 주로 조류와 같은 장거리 산 포에 유리한 척추동물에 의해 이루어지고 있는 것으로 추 측된다(How and Smallwood, 1982). 그러나 울릉도와 독도 의 식물 유입과 산포에 관한 연구는 거의 이루어져 있지 않아, 본 연구에서 정확한 정보를 제시하기엔 충분하지 않다. 울릉도와 독도에 분포하는 섬괴불나무의 유입경로 에 관한 연구는 엽록체 DNA coding region 그리고 핵 DNA 분석과 종자 산포 등의 연구와 같은 다양한 측면에서의 
연구가 더 이루어져야 할 것으로 생각된다.

본 연구에서는 울릉도와 독도의 섬괴불나무의 종내 변 이 및 다양성을 분석하고 지리적 분포 양상을 확인하였다. 본 연구 결과는 울릉도 및 독도 식물의 분자생물지리학적 연구로 대양섬의 생물학적 진화양상과 종 분화 과정에 중 요한 기초 자료로 활용될 것이다.

\section{사 사}

이 논문은 2012학년도 경북대학교 학술연구비에 의하 여 연구되었습니다.

\section{인용문헌}

Chung, M. K. 1985. Trees of China. Vol. 2: 1850-1865.

Cronquist, A. 1981. An intergrated system of classification of flowering plants. Columbia Univ. Press. Pp.1002-1016.

Doyle, J. J. and J. L. Doyle 1987. A rapid DNA isolation procedure for small quantities of fresh leaf tissue. Phytochemical Bulletin 19: 11-15.

Hamilton, M. B. 1999. Four primer pairs for the amplification of chlotoplast intergenic regions with intraspecific variation. Molecular Ecology 8: 521-523.

Heuertz, M., S. Fineschi and M. Anzidei. 2004. Chloroplast DNA variation and postglacial recolonization of common ash (Fraxinus excelsior L.) in Europe. Molecular Ecology 13: 3437-3452.

Hewitt, G. 2000. The genetic legacy of the Ice Ages. Nature 405: 907-913.

Howe, H. F. and J. Smallwood.1982. Ecology of seed dispersal. Annual Review of Ecology and Systematics 13: 201-228.

Jeon, S. H. 1993. Taxonomic Studies on the Genus Lonicera in Korea. MS Thesis. Seoul National University. (in Korea)

Johnson, L. A., and D. E. Soltis. 1994. matK DNA-sequences and phylogenetic reconstruction in Saxifragaceae s-str. Systematic Botany 19: 143-156.

Kim, Y. S. 1998. Plant ecosystem of Ulleung and Dokdo islands. A Synthetic Research of Ulleung and Dokdo islands, Pp.621-678. Yeungnam University Institute of Korean Culture, Gyeongsan. (in Korean)

Lee, C. and J. Wen. 2004. Phylogeny of Panax using chloroplast $\operatorname{trn} \mathrm{C}-\operatorname{tr} n \mathrm{D}$ intergenic region and the utility of $\operatorname{trn} \mathrm{C}-\operatorname{trn} \mathrm{D}$ in interspecific studies of plants. Molecular Phylogenetics and Evolution 31: 894-903.

Lee, T. B. 1979. Illustrated flora of Korea. Hyangmunsa, Seoul. Pp. 696-701.

Lee, W. T. 1996. Lineamenta Florae Koreae. Acadamy Press, Seoul. (in Korean)
Lee, W. and J.-H. Pak. 2010. Intraspecific sequence variation of trn $\mathrm{L} / \mathrm{F}$ intergenic region (cpDNA) in Sedum takesimense Naku (Crassulaceae) and aspects of geographic distribution Korean Journal of Plant Taxonomy 40: 157-162.

Nakai, T. 1927. Trees and shrubs indigenous in Japan Proper. Tokyo, Vol.1: 628-687.

Nakai, T. 1938. A new classification of the genus Lonicera in the Japanese Empire together with the diagnoses of new species and new varieties. The Journal of Japanese Botany Vol. XIV(6): 359-375.

Ohwi, J. 1984. Flora of Japan. National Science Museum. Tokyo. Pp. 839-843.

Jakubowsky, M. G., P. M. Schluter, T. Fer, H. Kato, T. F. Stuessy and B.-Y. Sun. 2006. Evolution of Dystaenia takesimana (Apiaceae) edemic to Ulleung Island, Korea. Plant Systematics and Evolution 256: 159-170.

Rendell, S. and R. A. Ennos. 2003. Chloroplast DNA diversity of the dioecious European tree Ilex aquifolium L. (English holly). Molecular Ecology 12: 2681-2688.

Schaal, B. A., D. A. Hayworth, K. M. Oseni, J. Rauscher and W. A. Smith. 1998. Phylogeographic studies in plants: problems and prospects. Molecular Ecology 7: 465-474.

Sun, B. Y. and T. F. Stuessy. 1998. Preliminary observations on the evolution of endemic angiosperms of Ulleung Island, Korea. Evolution and Speciation of island plants. Combridge University Press, UK. Pp. 181-202.

Sun, B. Y., M. R. Sul, J. A. Im, C. H. Kim and T. J. Kim. 2002. Evolution of endemic vascular plants of Ulleungdo and Dokdo in Korea-floristic and cytotaxonomic characteristics of vascular flora of Dokdo. Korean Journal of Plant Taxonomy 32: 143-158.

Swofford, D. L. 2002. PAUP*. Phylogenetic analysis using parsimony (*and other method). Version 4.0b10. Sinauer Associates, Sunderland, Mass.

Taberlet, P., L. Gielly, G. Pautou and J. Bouvet. 1991. Universal primer for amplification of three non-coding regions of chloroplast DNA. Plant Molecular Biology 17: 1105-1109.

Taberlet, P., L. Fumagali, A. G. Wust-Saucy and J. F. Cosson. 1998. Comparative phylogeography and postglacial colonization routes in Europe. Molecular Ecology 7: 453-464.

Thompson, J. D., T. J. Gibson, F. Plewniak, F. Jeanmougin and D. G. Higins. 1997.The CLUSTAL X windows interface: flexible strategies for multiple sequence alignment aided by quality analysis tools. Nucleic Acids Research 22: 4676-4882. 